\title{
The Character of Board of Director, Supervisors and Agency Cost of Charity Foundations in China
}

\author{
Xiaoxia XIE \\ Associate Professor, School of Public Administration \\ Beihang University, Beijing, China, 100191
}

\author{
Yufei TANG* \\ Undergraduate student, School of Public Administration \\ Beihang University, Beijing,China,100191 \\ e-mail: xiexx@buaa.edu.cn \\ *Corresponding author
}

\author{
Yue MING \\ Granduate student, School of Public Administration \\ Beihang University, Beijing, China,100191
}

\begin{abstract}
Charity foundation internal governance as a hot topic in both theory and practice are concerned. However little literature has discussed the relationship between the character of Board of Director, Supervisors and agency costs. This research studies 213 charity foundations during the period from 2011 to 2012 , and tries to investigate and answer the following two questions: firstly, the impact of charity foundations' Board of director and Supervisors on agency costs. Secondly, whether charity foundations' internal governance can effectively reduce agency costs. Our conclusions include: Firstly, the bigger size of the foundation Board of Director, the more beneficial to reduce agency costs .Secondly, it's not conducive to reducing agency costs when the board of director often holds meetings and when chairman and general secretary share the dual identity. Thirdly, charity foundations' Board of Supervisors had no significant effect on reducing agency costs. The current empirical discovery helps to explain the relationship between charity foundations' board of director and board of supervisor and agency cost. The conclusions provide empirical research evidence to support some policies of supervising charity foundations' internal governance to be built.
\end{abstract}

Keywords-Charity foundations; Board of director; Board of supervisor; Agency cost

\section{INTRODUCTION}

Agency issues are not only widespread in modern companies, but are also prevalent in modern charity foundations. Charity Foundations, as typical non-profit organizations, have the characteristics as follows: first, non-profit. Charity foundations are usually not profitable, even if the charity foundations gain profits in the course of the operation, the profits are not allocated to the property owner, but continue to serve as the financial resources of philanthropy activities. Second, the particularity of the goal. Unlike the goals of survival, development and profitability of for-profit organizations like enterprises, the goal of charity foundations is to use their own and social resources to help groups that need help and promote social progress, the social value of theirs is far greater than the economic value. Thus, for the property owners who create charity foundations, the purpose of creating the charity foundations is to maximize the social value of theirs. However, apart from the property owners (or founders), the charity foundations are also related to a number of other stakeholders, including internal councils, secretary-generals, board of supervisors, staff; external donors, donation recipients, regulators such as government, the media and the public, etc. According to the theory of corporate governance, in enterprises that the ownership and management right are separated, the difference between the principal and the agent's goal leads to the opportunistic behavior of the agents, to violate the interests of the client for the benefit of themselves. This will result in the decrease of the value of the company [11]. A lot of empirical evidence suggests that the agency costs between managers and shareholders significantly affect corporate finance decisions, investment decisions and corporate value. Are there also agency issues, arising from inconsistencies in the interests of property owners and managers, in such non-profit organizations as charity foundations? What is the relationship between the board of supervisors and the agency costs? These are the focuses of this paper.

\section{A Theories and Hypothesis}

Over the past two decades, the researchers have formed a corporate governance theoretical research system through unremitting efforts. The study of corporate governance focused on the relationship among corporate performance, the role of the board and the characteristics of state governance.

According to the results of domestic and international researches, the traditional, general corporate governance mechanism, to some extent, can be applied to the study of non-profit organizations' governance structure. However, as for charity foundation, which is a typical type of non-profit organization, the study of its internal governance structure cannot be fully in accordance with that of the profit-oriented organizations'.

Combined with the characteristics of the current Chinese charity foundations, this paper has mainly made the following assumptions:

H1: The larger the board of directors of charitable foundations, the more conductive it is to reducing agency costs.

H2: The more meetings held by the board of directors of charity foundations each year, the less conductive it is to reducing agency costs. 
H3: When charity foundations' chairman and secretary is the same person, it is not conducive to the reduction of agency costs.

H4: The longer the term of office of the secretary-general of charity foundations, the higher the agency costs are.

H5: The greater the scale of the board of supervisors of charity foundations, the more conducive it is to reducing agency costs.

H6: The more meetings the charity foundations' board of supervisors hold, the more conducive it is to reducing agency costs.

\section{B Model Design}

In order to test the assumptions above, the following regression model (1), model (2) and model (3) are

$$
\begin{aligned}
\text { AOR }= & \alpha_{0}+\alpha_{1} \text { Dual }+\alpha_{2} \text { Bsize }+\alpha_{3} \text { Asize }+\alpha_{4} B M+\alpha_{5} A M+\alpha_{6} C E O T \\
& +\alpha_{7} \text { Ponp }+\alpha_{8} \text { Size }+\varepsilon_{i} \\
\text { AER }= & \beta_{0}+\beta_{1} \text { Dual }+\beta_{2} \text { Bsize }+\beta_{3} \text { Asize }+\beta_{4} B M+\beta_{5} A M+\beta_{6} C E O T \\
& +\beta_{7} \text { Ponp }+\beta_{8} \text { Size }+\varepsilon_{i} \\
C F=\gamma_{0} & +\gamma_{1} \text { Dual }+\gamma_{2} \text { Bsize }+\gamma_{3} \text { Asize }+\gamma_{4} B M+\gamma_{5} A M+\gamma_{6} C E O T \\
& +\gamma_{7} \text { Ponp }+\gamma_{8} \text { Size }+\varepsilon_{i}
\end{aligned}
$$

\begin{tabular}{|c|c|c|c|}
\hline Variable & \multicolumn{2}{|c|}{ Variable definition } & Variable description \\
\hline AOR & \multirow{3}{*}{$\begin{array}{l}\text { Agency } \\
\text { costs }\end{array}$} & $\underline{\text { Asset utilization }}$ & $\begin{array}{l}\text { The year end number of reported annual business activity cost/the year } \\
\text { end number of reported annual assets }\end{array}$ \\
\hline AER & & Asset cost rate & $\begin{array}{l}\text { The year end number of reported annual administration expenses/ the } \\
\text { year end number of reported annual assets }\end{array}$ \\
\hline $\mathbf{C F}$ & & Cash flow & $\operatorname{Ln}($ the net increase of reported annualcash and cash equivalents) \\
\hline Dual & \multicolumn{2}{|c|}{$\begin{array}{l}\text { Whether chairman and secretary } \\
\text { are the same person }\end{array}$} & $\begin{array}{l}\text { If the chairman and secretary are the same person in the reporting year, } \\
\text { code Dual as } 1 \text {; else, } 0\end{array}$ \\
\hline Bsize & \multicolumn{2}{|c|}{ The size of the board of directors } & The number of people of the board of directors in the reporting year \\
\hline Asize & \multicolumn{2}{|c|}{$\begin{array}{l}\text { The size of the board of } \\
\text { supervisors }\end{array}$} & The number of people of the board of supervisors in the reporting year \\
\hline BM & \multicolumn{2}{|c|}{$\begin{array}{l}\text { The meeting times of the board } \\
\text { of directors }\end{array}$} & The meeting times of the board of directors in the reporting year \\
\hline $\mathbf{A M}$ & \multicolumn{2}{|c|}{$\begin{array}{l}\text { The meeting times of the board } \\
\text { of supervisors }\end{array}$} & The meeting times of the board of supervisors in the reporting year \\
\hline CEOT & \multicolumn{2}{|c|}{$\begin{array}{l}\text { Term of office of the } \\
\text { secretary-general }\end{array}$} & Term of office of the secretary-general \\
\hline Ponp & \multirow[t]{2}{*}{$\begin{array}{l}\text { Control } \\
\text { variables }\end{array}$} & $\begin{array}{l}\text { The nature of } \\
\text { the charity } \\
\text { foundation }\end{array}$ & National foundations are coded as 1 ; local foundations are coded as 0 \\
\hline Size & & $\begin{array}{l}\text { The size of the } \\
\text { charity } \\
\text { organization }\end{array}$ & Ln(the year end number of reported annual assets) \\
\hline
\end{tabular}

TABLE I. RELEVANT VARIABLE DEFINITIONS

\section{Descriptive Statistics}

According to Table 2, the mean and the standard deviation of AOR are 0.41 and 0.52 respectively, which means the rate of asset of charitable foundations differs a lot in China. The maximum and minimum of AER are 0 and 0.22 respectively, and the mean and the standard 
deviation of AER are 0.02 and 0.029, which suggests that the rate of expense to asset of charitable foundations is varied in China. The maximum and minimum of CF are 0 and 20.26 respectively, and the standard deviation is 7.933, which indicates that cash flow of Chinese charitable foundations differs greatly. The mean of Dual is 0.1 , stating that it is not common that the board director is the same as the secretary general in Chinese charitable foundations. The maximum and minimum of Bsize are 162 and 2 respectively, and the mean and the standard deviation are 15.83 and 11.865 . It explains that the difference of size of board of director is a little large and the average size is about 15 . The maximum and minimum of Asize are 7 and 1 respectively, and the mean and the standard deviation are 1.79 and 1.066. The result illustrates that the difference of size of board of supervisory is also a little large and the average size is between 1 and 2 . The fact that the maximum and minimum of BM are 10 and 1 respectively reveals that the number of times which the board of director holds a conference is very different among Chinese charitable foundations. And the mean of BM is 2.2, demonstrating that the average numbers of times are between 2 and 3 . The fact that the maximum and minimum of AM which are 10 and 0 respectively reveals that the number of times which the board of supervisory holds a conference is also different among Chinese charitable foundations. And the mean of AM is 1.98, demonstrating that the average numbers of times are between 1 and 2 . The maximum and minimum of CEOT are 15 and 0 respectively, and the mean and the standard deviation are 3.57 and 2.455 . It testifies that the longest-serving of supervisors is 15 years in Chinese charitable foundations and the average term is between 3 and 4 years. Also, there are obvious differences in term of supervisors among different charitable foundations.

\section{TABLE II. RESUlTS OF DESCRIPTIVE STATISTICS}

\begin{tabular}{l|l|l|l|l|l}
\hline $\begin{array}{l}\text { Varia } \\
\text { bles }\end{array}$ & $\mathrm{N}$ & Minimum & Maximum & Mean & S.D \\
\hline AOR & 213 & 0 & 3.86 & 0.41 & 0.52 \\
\hline AER & 213 & 0 & 0.22 & 0.02 & .029 \\
\hline CF & 213 & 0 & 20.26 & 9.82 & 7.933 \\
\hline Dual & 213 & 0 & 1 & 0.10 & 0.305 \\
\hline Bsize & 213 & 2 & 162 & 15.83 & 11.865 \\
\hline Asize & 213 & 1 & 7 & 1.79 & 1.066 \\
\hline BM & 213 & 1 & 10 & 2.20 & 0.951 \\
\hline AM & 213 & 0 & 10 & 1.98 & 0.890 \\
\hline CEOT & 213 & 0 & 15 & 3.57 & 2.455 \\
\hline Ponp & 213 & 0 & 1 & 0.49 & 0.501 \\
\hline Size & 213 & 13.75 & 21.73 & 17.89 & 1.299 \\
\hline
\end{tabular}

\section{RESULTS OF REGRESSION ANALYSIS}

Table 3 shows that Adj.R2 of the first model which variable agency costs is AOR is 0.216. Adj.R2 of the second model which variable agency costs is AER is 0.195. Adj.R2 of the third model which variable agency costs is $\mathrm{CF}$ is 0.071. Comparing these three results, the first model has the highest goodness of fit, and F-statistics of all the models are all pass the statistical test.

TABLE III. THE RESULTS OF REGRESSION

\begin{tabular}{l|l|l|l}
\hline \multirow{2}{*}{ Variables } & Model(1) & Model(2) & Model(3) \\
\cline { 2 - 4 } & Variable Agency Cost is AOR & Variable Agency Cost is AER & Variable Agency Cost is CF \\
\hline $\mathrm{c}$ & $0.153(0.321)$ & $0.115^{* *}(4.274)$ & $-14.234(-1.789)$ \\
\hline Dual & $-0.021(-0.190)$ & $-0.005(-0.859)$ & $-4.055^{* *}(-2.226)$ \\
\hline Bsize & $0.015^{* *}(4.799)$ & $0.000(1.377)$ & $-0.076(-1.470)$ \\
\hline Asize & $-0.059(-1.734)$ & $-0.001(-0.765)$ & $-0.812(-1.427)$ \\
\hline BM & $-0.042(-0.814)$ & $0.006^{* *}(2.164)$ & $-0.22(-0.256)$ \\
\hline AM & $0.037(0.666)$ & $-0.002(-0.66)$ & $0.936(1.019)$ \\
\hline CEOT & $0.014(1.005)$ & $0.001(1.607)$ & $-0.169(-0.741)$ \\
\hline Ponp & $0.307 * *(4.641)$ & $0.014^{* *(3.781)}$ & $1.776(1.604)$ \\
\hline Size & $-0.003(-0.124)$ & $-0.007 * *(-4.432)$ & $1.424^{* *(3.209)}$ \\
\hline N & 213 & 213 & 213 \\
\hline R2 & 0.246 & 0.226 & 0.106 \\
\hline Adj.R2 & 0.216 & 0.195 & 0.071 \\
\hline F & $8.312(\mathrm{P}=0.000)$ & $7.354(\mathrm{P}=0.000)$ & $3.034(\mathrm{P}=0.003)$ \\
\hline
\end{tabular}

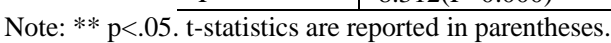

Specifically, the regression analysis results of first model illustrates that the estimation value of Bsize is 0.015 . So it passes the statistical test with significance level of $5 \%$. The estimation value of Ponp is 0.307 , passing the statistical test with significance level of $5 \%$. However, the estimation values of other variables do not pass the statistical test with significance level of 5\%. The regression analysis results of second model illustrates that the estimation values of BM and Size are 0.006 and -0.007 respectively, both passing the statistical test with significance level of $5 \%$. And the estimation value of Ponp is 0.014 , which also passes the statistical test with significance level of $5 \%$. The estimation values of other variables do not pass the statistical test with significance level of $5 \%$. The regression analysis results of third model illustrates that the estimation values of Dual and Size are -4.055 and 1.424 respectively, both passing the statistical test with significance level of $5 \%$. The estimation values of other variables do not pass the statistical test with significance level of $5 \%$. In terms of he regression analysis results of these three model, Bsize, BM, Dual, Ponp and Size have influences on agency cost of charitable foundations. It also shows that H1, H2 
and $\mathrm{H} 3$ are confirmed and $\mathrm{H} 4, \mathrm{H} 5$ and $\mathrm{H} 6$ do not be verified validly.

\section{CONCLUSIONS}

This paper through empirical research analyzes the relationships between board of director and board of supervisory and agency cost. We find that:

The larger size of board of director is, the more advantageous to reduce agency costs of charitable foundations. The more numbers of times which the board of director holds a conference, the more disadvantageous to reduce agency costs. The fact that the board director is the same as the secretary general is disadvantageous to reduce agency costs. If the board director is the same as the secretary general, it is more disadvantageous to reduce agency costs and to improve administrative efficiency.

Because charitable foundations are typically non-profit organizations, the higher cash flow means that the management has better ability to raise money. And the better ability to raise money would bring more stakeholders, which is advantageous to improve external supervision from stakeholders to managers of charitable foundations and then reduce agency costs.

In conclusion, this paper empirically analyses the relationships between the board of director, the board of supervisory and agency cost, and draw the following conclusions by taking models and regression analysis: the larger size of board of director is, the more advantageous to reduce agency costs of charitable foundations; the more numbers of times which the board of director holds a conference, the more disadvantageous to reduce agency costs; the board director is the same as the secretary general which is disadvantageous to reduce agency costs. However, this paper still has some limitations. For example, H4, H5 and $\mathrm{H} 6$ do not get confirmed by regression analysis, which means that in this paper we do not find the relationships between internal government structure, especially the term of secretary general, the size of the board of supervisory and the numbers of times which the board of supervisory holds a conference, and agency cost of charitable foundations. The direction of continuing research in the future would be building and analyzing structural equation model between internal government structure and agency cost, which uses agency cost as internal variable and above-mentioned variables as external variables.

\section{REFERENCE}

[1] Adams, R.B., Hermalin, B.E., Weisbach, M.S. The Role of Boards of Directors in Corporate Governance: A Conceptual Framework and Survey [J].Journal of Economic Literature, 2010(48):58-107.

[2] Borokhovich, K.A., Parrino, R., Trapani, T. Outside Directors and CEO Selection [J]. Journal of Financial and Quantitative Analysis, 1996, 31(3):337-355.

[3] Brochet, F., Faurel, L., McVay, S.E.Manager-Specific Effects on Earnings Guidance: An Analysis of Top Executive Turnovers [J]. Journal of Accounting Research, 2011, 49(5):1123-1162.

[4] Brennan, N.M., Solomon, J.Corporate Governance, Accountability and Mechanisms of Accountability: an Overview [J]. Accounting, Auditing and Accountability Journal, 2008, 21(7):885-906.

[5] Farrell, K.N. Different Forms of Difference in Multi-level Governance for Sustainability: connections between gender and complexity theory perspectives [J]. Der öffentliche Sektor, 2005, 31(1/2):9-19.

[6] Hermalin, B.E., Weisbach, M.S. Endogenously Chosen Boards of Directors and Their Monitoring of the CEO [J]. The American Economic Review, 1998, 88(1):96-118.

[7] Jiraporn, P., Davidson III, W.N., Qian, H.MBO Withdrawal and Determinants of Stockholders' Wealth [J]. Quarterly Journal of Business and Economics, 2004, 43(3/4):13-29.

[8] Kumar, P., Sivaramakrishnan, K. Who Monitors the Monitor? The Effect of Board Independence on Executive Compensation and Firm Value [J]. Review of Financial Studies, 2008, 21(3):1371-1401.

[9] Mather, P.Financial Covenants in Australian Bank Loan Contracts: Incidence, Measurement Rules and Monitoring [J]. Australian Accounting Review, 1999, 9(1):63-73.

[10] Michael, C., Jensen, M.C. Agency Costs of Free Cash Flow, Corporate Finance, and Takeovers [J]. American Economic Review, 1986, 76(2):323-329.

[11] Nagar, V., Petroni, K.R., Wolfenzon, D. Governance Problems in Closely-Held Corporations[J].Journal of Financial and Quantitative Analysis, 2011, 46(4):943-966.

[12] Peterson, D.K. Agency Perspectives on Ngo Governance [J] Journal of Management Research, 2010(2):1-11.

[13] Vafeas, N., Theodorou, E.The Relationship between Board Structure and Firm Performance in the UK [J]. British Accounting Review, 1998, 30(4):383-407.

[14] Van Den Berghe, L.A.A., Levrau, A. Evaluating Boards of Directors: What Constitutes a Good Corporate Board? [J]. Corporate Governance: An International Review, 2004, 12(4):461-478

[15] Walsh, J.P.CEO Compensation and the Responsibilities of the Business Scholar to Society [J]. Academy of Management Perspectives, 2008, 22(2):26-33 